\title{
Options for land conservation practices based on land use and land degradation in upland Luas Watershed Bengkulu Indonesia
}

\author{
Muhammad Faiz Barchia ${ }^{1, *}$, Khairul Amri ${ }^{2}$, Friski Namura $^{2}$ \\ ${ }^{1}$ Soil Science Department, Faculty of Agriculture University of Bengkulu, 38371 Bengkulu, Indonesia \\ ${ }^{2}$ Civil Engineering Department Faculty of Engineering University of Bengkulu, 38371 Bengkulu, Indonesia
}

\begin{abstract}
This study is objected to determine the options for land conservation based on degraded land in upland of Luas watershed, Bengkulu, Indonesia. This work was conducted on the upland from November 2015 to February 2016. The location was geographically lying on $103^{0} 20^{\prime} 47^{\prime \prime}-103^{0} 58^{\prime} 50^{\prime \prime}$ Latitude., and on $04^{0} 21$ ' 10 " - $04^{0} 37$ ' 12 " longitude, in Kaur District, Bengkulu Province. The total area is 55,045.23 ha where the forest covers $52,432.95$ ha or $95 \%$ of the upland of Luas watershed. The spatial analysis for land degraded level was based on overlaying from attributes of some parameters such as; land cover, slope, erosion hazardous level, land productivity and management. The analysis is conducted by converting analytical geographical coordinates into Universal Transverse Mercator (UTM). The upland of the watershed is currently under environmentally pressures which around $24 \%$ in poor conditions and $23 \%$ of the area are degraded. The Limited Timber Forest areas of Air Kinal, Kaur Selatan, and the protected forest area of Bukit Raja Mendara can potentially be rehabilitated by applying concepts of social forestry with introducing agro-forestry cultivation models. All areas of agriculture cultivation in this study can be effective using land conservation tillage and management which concerning all environmental values for the sustainable productivities.
\end{abstract}

\section{Introduction}

Watershed in a hydrological concept is an important element in the water management system. Watershed as a component in the systems transforms rainfall to be runoff and other water characteristics [1]. Watershed plays important rules on the ecosystem sustainability, considering interactions within, and surrounding of it through of human life [2]. Sustainable ecosystems are maintained when interactions whole components in the systems well run and stabilized by each other [3]. Threaten to one of the ecosystem elements influence one or some other components with effects of continuous destabilization human ecosystems [4].

Nowadays, there are 458 of watersheds in Indonesia are reported under critical conditions. It is estimated that 60 of the watersheds are in high priority for rehabilitation. Otherwise, a number of 222 watersheds are in the second priority due to poor environmental values, and 176 of the Indonesia watersheds are in the third priority. The degraded lands covered watershed with forest functions in numbers of 19,506,487 ha, and of 10,690,311 ha in agriculture lands [5]. Increasing degraded land productivities within forest areas and agriculture cultivated land is not only in the down- and middle-stream areas but also continuous encroachment to upland watershed. It is known, that the watershed degradation have been tirggered by increasing exploitation of natural resources due to rapid population, economic growth, lack of experiences in watershed management and practices [6]. In the management planning and integrated conservation practices, it requires some important strategies and innovative actions in order to improve and maintain the land productivities and watershed surrounding values [7].

The landforms and watersheds in Bengkulu area has different characteristics than others. The distance between upstream and downstream are relatively short. It is around $10 \mathrm{~km}$ with narrow boundaries [8]. Some watersheds in Bengkulu, as like in Luas watershed, have been lost its natural and social function. Agriculture land and forest areas on the upland Luas watershed, are under intensive cultivation practices by both traditional farmers and coming from out the area. The cultivation practices on the upland Luas watershed have not been applied well by considering good agricultural practices. It was applied by un-integrated planning for whole functions of ecosystem components of the upland Luas watershed. In the future, the integrated management planning and technical conservation practices should be focus on the improvement of the upland of Luas watershed. Therefore, empowerment of the natural resources on the Luas watershed could optimally harvested in peak of productivities and in long running for sustainable environmental values.

Corresponding author: faiz barchia@yahoo.com 


\section{Materials and method}

The upland of Luas watershed lies on $103^{0} 20^{\prime} 47^{\prime \prime}$ $103^{0} 58^{\prime} 50$ " Latitude., and on $04^{0} 21^{\prime} 10^{\prime \prime}$ - 04037'12" Longitude., in Kaur District, Bengkulu Province with covering area of 55,119.37 ha (Fig. 1).

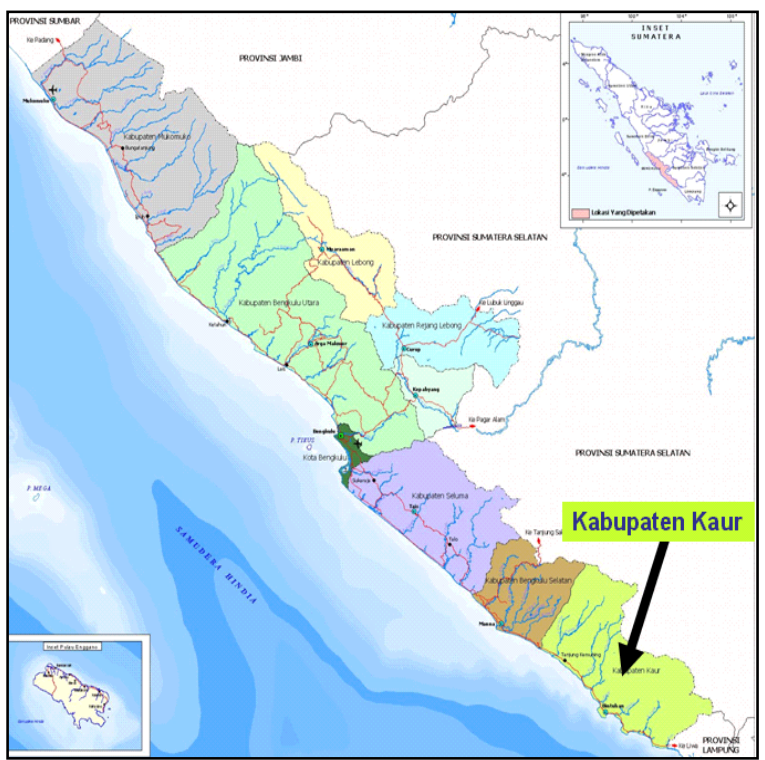

Fig. 1. Map of Kaur District, Bengkulu Province, Indonesia

This research is related to previous conducted research as reported in [9]. It consisted the analysis in general view for the whole degraded land conditions on upland Luas watershed. In this work, the most concerns are in determining the options of land conservation practices based on land use and environmental values management.

The land degradation degrees on different land use based on Rules of Directorate General for Land Rehabilitation and Social Forestry, Ministry of Forestry, Republic of Indonesia No. P.4/V-SET/2013 [10]. The spatial analysis for land degraded level was based on overlaying from attributes of land cover, slope, erosion hazardous level, land productivity and management. The spatial analysis was converted from analytical geographical coordinates to Universal Transverse Mercator (UTM) [11]. Secondary data collected related with this research were validated through ground check in some location in field to perform the data. Options for land management practices were different between agriculture area and forestry area $[12 ; 13]$, and other related references.

In orger to figure out the options of land conservation and management practices based on land use and functions, it required a map of Indonesia landforms and digital ALOS photos released from Geospatial Information Agency, Republic of Indonesia, spatial data of upland Luas watershed from Ketahun Watershed Management Office (BPDAS Ketahun) Bengkulu, Ministry of Environment and Forestry, Republic of Indonesia.

\section{Results and discussion}

The Luas watershed is commonly provided some functions such as forest protection on Bukit Raja Mendara for water recharge, limited timber forest of Air Kinal and, Kaur Selatan, Bukit Barisan Selatan National Park. It also protect the traditional agriculture cultivation areas. The land function on the upland Luas watershed are mostly in form of forest with land cover of 52,432.95 ha, or $95.25 \%$ of the upland, meanwhile the protected forest covers of $47,948.56$ ha, or of $87.11 \%$ of total area. The agricultural cultivated lands are $2,612.28$ ha or only $4.75 \%$ of the upland area.

The forest land in the upland Luas watershed are in intensive pressure due to agricultural cultivated land uses by traditional farmers. It caused a fast land deterioration in the upland of Luas watershed. When the watershed in a degraded condition, so all components to form and related to the watershed are suffered. The levels of degraded land condition on the upland of Luas watershed are more widespread. It is not only on traditional agriculture area, but it also exterminated until area of Bukit Barisan Selatan National Park, limited timber forest, and forest protected as shown in Table 1. The distribution critical lands based on degradation levels for the whole land functions on the upland Luas watershed are shown in Figure 2.

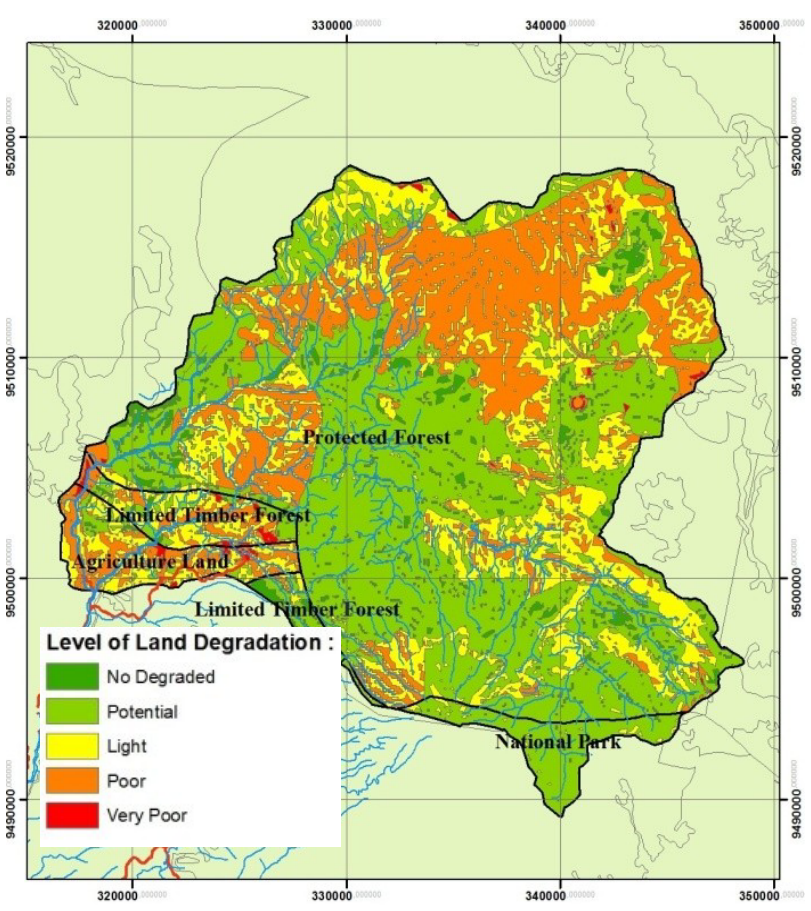

Fig.2. Degraded land in the upland Luas watershed

As shown in Table 1 and Figure 2, the level of degraded lands was performed from the minimum to the poorest area. It very poor area reached to $26,326.93 \mathrm{ha}$, or of $47.83 \%$ from the upland Luas watershed. At the same time, the areas were threated due to unwise cultivation practices with the potentially deteriorated level reached to $26,430.39$ ha, or $48.01 \%$. 
Table 1. Wide areas of degraded land on upland Luas watershed Bengkulu Indonesia

\begin{tabular}{|l|c|c|c|c|c|c|}
\hline \multirow{2}{*}{ Degraded Level } & \multicolumn{3}{|c|}{ Wide Area of Forests (Ha) } & \multirow{2}{*}{ Agriculture } \\
\cline { 2 - 4 } & $\begin{array}{c}\text { Protected } \\
\text { Forest }\end{array}$ & $\begin{array}{c}\text { Limited Timber } \\
\text { Forest }\end{array}$ & $\begin{array}{c}\text { Bukit Barisan } \\
\text { Selatan National } \\
\text { Park }\end{array}$ & $\begin{array}{c}\text { Total } \\
\text { Area }\end{array}$ & \\
\hline No Degraded & $1,985.91$ & 249.92 & 21.40 & 30.68 & $2,287.91$ & 4.15 \\
\hline Potential Degraded & $23,558.96$ & 814.07 & $1,751.90$ & 305.46 & $26,430.39$ & 48.01 \\
\hline Light Degraded & $10,864.72$ & 841.11 & 94.67 & $1,127.62$ & $12,928.12$ & 23.48 \\
\hline Degraded & $11,423.12$ & 582.09 & 0.66 & $1,060.38$ & $13,066.25$ & 23.74 \\
\hline Poor Degraded & 115.85 & 128.57 & 0 & 88.14 & 332.56 & 0.60 \\
\hline$\Sigma$ & $47,948.56$ & $2,615.76$ & $1,868.63$ & $2,612.28$ & $55,119.37$ & 100.00 \\
\hline
\end{tabular}

Based on forest and land functions, the watershed should be performed as service areas for water interception and re-charge, biodiversity sources, and other forest functions, options for conservation practices. In order to restore forest productivities in the upland Luas, it should be designed and developed in same concept by considering the traditional farmers. The better options for conservation practices over the protected forest areas are by applying some developed models of social forestry with introducing agro-forestry cropping systems. There are several choices of plants in the agro-forestry model which commonly using multi purposes plant species. Those options can potentially lead farmers to harvest only non-wood forest products such as various fruits, root-crops, sap, resin, etc. Crops choice for this model involved durian, rubber crops, jackfruit, bread-fruit, candle-nuts, etc. The protected forest area should be rehabilitated in width of 22,403.69 ha. The visualization of the protected forest should be re-planted with the social forestry model as seen on Figure 3.

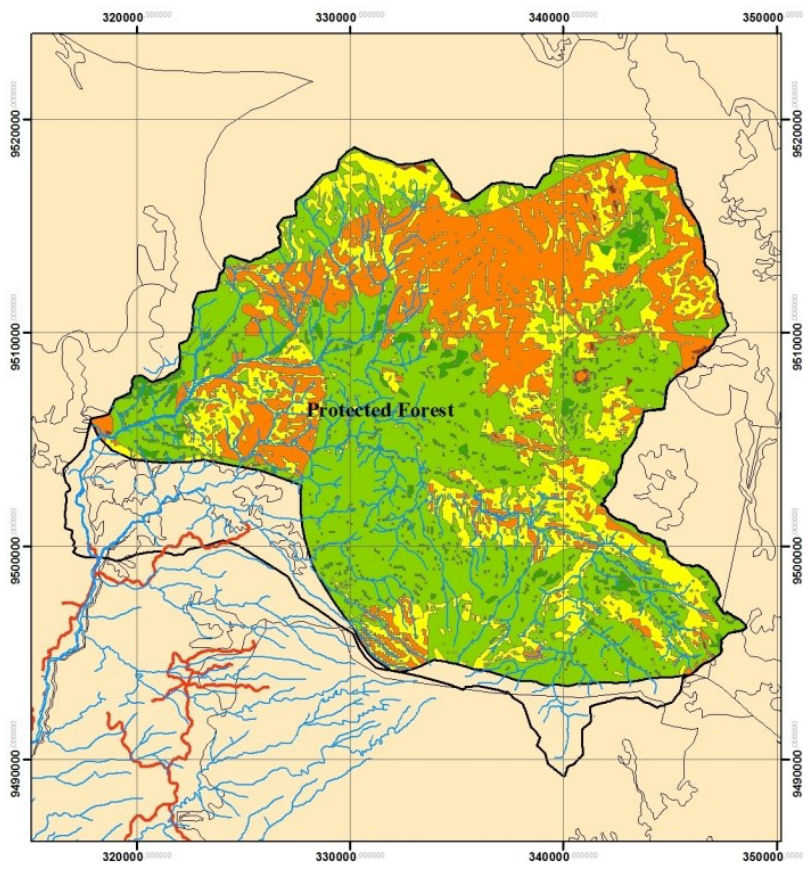

Fig. 3. Agro-forestry, option for conservation practice on protected forest
The limited timber forests on the upland Luas watershed was 2,615.76 ha. The widest area of limited timber forest was located on the middle of Luas watershed. The limited timber forests also cultivated by traditional farmers for coffee plantation. Recently, the land productivities are decreased due to land degradation in around of $1,551.77$ ha or $59.32 \%$ of the limited timber forest. The models for forest restoration on the timber forest could be conducted with engagement through social forestry program, therefore the surrounding societies in the forest will take an advantage by harvesting non wood forest products. The asre should be be restored in term of its functions as timber forest through the social forestry. The distribution areas are revealed in Figure 4.

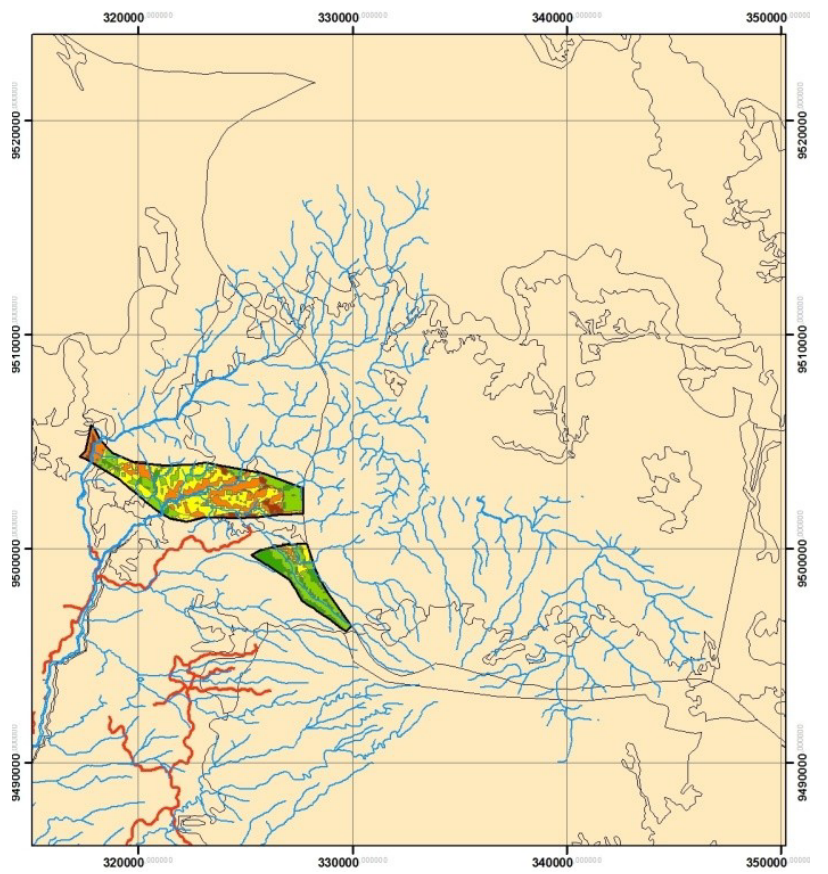

Fig. 4. Agro-forestry, option for conservation practice on limited timber forest

Some forest encroachment were found for land cultivation of agricultural activities in the upland Luas watershed. It also happened to Bukit Barisan Selatan National Park with small area of 95.33 ha or $5.10 \%$ of 
the National Park. However, it indicated a threaten for sustainability in natural sources on the forest functions on the National Park in the future. The distribution area that should be re-vegetation at Bukit Barisan Selatan National Park on the upstream of Luas Watershed are shown on Figure 5.

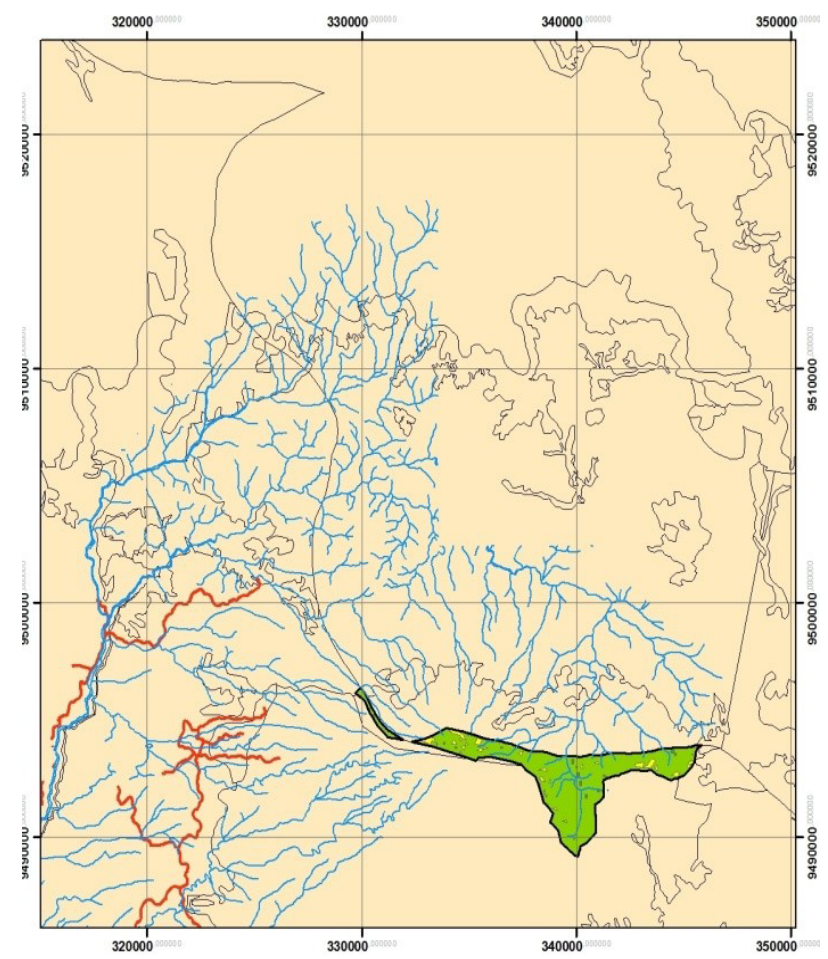

Fig. 5. Reforestry, option for conservation practice on Bukit Barisan Selatan National Park

Some efforts are necessary to conduct in order to protect the Bukit Barisan Selatan National Park from encroachment. The degraded land on the National Park should be rehabilitate by plantation using local plant seeds. All agricultural activities and people living in the Bukit Barisan Selatan National Park need to re-settle out of the location. In this park, it was found huge biodiversities in the ecosystems, therefore it should be protected carefully from any potential disasters.

The area of agricultural cultivated land on the upland of Luas Watershed are 2,612.28 ha, or only covers $4.74 \%$. Meanwhile, from all the agricultural land area, there are $2,276.14$ ha, or $87.13 \%$ of the cultivated lands were under deteriorated conditions. It is found in low degree to the highest level of land degradation. This condition indicated that when a decrease in productivities occurred on the agricultural cultivated lands, there will be an expansion of encroachment in the forest areas due to incoming of new traditional farmers from surrounding or out-side Kaur District. For this reason, empowerment of local societies is required to improve the land productivities using appropriate technologies. There are several options in conservation practices on agricultural land, such as; minimum tillage, bench terrace, and agro-forestry. Options for conservation practices on agricultural cultivated land in the upland of Luas watershed are shown on Figure 6.

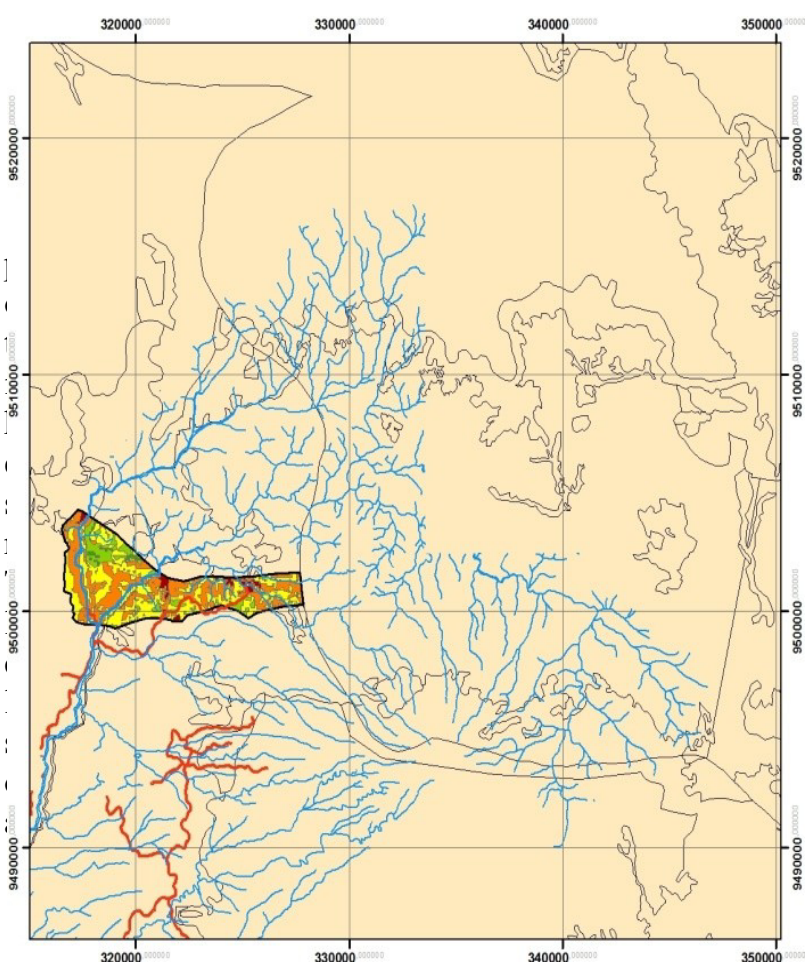

\section{Conclusions}

The upland of Luas watershed mostly covers by forest area of $52,432.95$ ha, or of $95.25 \%$ of total area in the watershed. It consists of protected forest of Bukit Raja Mendara, Limited Timber Forest of Air Kinal and Kaur Selatan, and the National Park of Bukit Barisan Selatan. On the area of Bukit Barisan Selatan National Park, it is found area of 95.33 ha that urgently to be restored. The options for land conservation and management practices may be proceed with reforestation using local plant species with starter seeds. Agricultural and social activities on the National Park must be persuasively deported from this area.

The forest protection with area of $22,403.69$ ha and the limited timber forest with area of $1,551.77$ ha are detected as land degradation. The area distribution are varied from light to heavy level of degradation. Furthermore, this condition led to a program of land rehabilitation in order to increase the land productivity. Those areas could be developed as social forestry through empowerment society around the forest by planting multi-purposes tree species.

The agricultural cultivated land on the upland of Luas Watershed are covers only of 2,612.28 ha, but the productivity of $87.13 \%$ of the land was depleted. The degraded agriculture land should be cultivated by considering environmental values synergistically with the long run of improvement in land productivities and sustainable agriculture. The options for land management practices on the agriculture area can be applied by planting cover crops with minimum tillage, with credit and/or bench terraces. 


\section{References}

1. I.G.Tunas. Jurnal Smartek. 3, 3 pp 137-145 (2005).

2. Hoff, Holger. Proc 5th Rosenberg Int Forum on Water Policy, Banff, Alberta, Canada. September. (2006).

3. C. Asdak. Book. Gadjah Mada Univerisity Press. Yogyakarta (2014).

4. D.I.D Arini, L.B. Prasetyo, and O. Rusdiana. Media Konservasi. 12, 2 (2007). http://journal.ipb.ac.id index.php/konservasi/article/view/2985

5. H. Santoso. Report of Coordination Meeting on Integrated Watershed Management. Batam. Indonesia. March 23 (2011).

6. K. Amri., A. Halim., Ngudiantoro, and M.F. Barchia. APCBEE Procedia. 3: 235-249 (2014).

7. I.E. Soegiri. Report. Coordination Meeting on

8. Integrated Watershed Management. Batam. Indonesia. March 23 (2011).
9. A. Farianto., K. Amri and M. Ali. Report. repository.unib.ac.id/4239 (2012).

10. F. Namura. Thesis. University of Bengkulu. Indonesia (2016).

11. Directorate General of Watershed Management and Social Forestry. Guide Book. www.bpdasps.dephut.go.id, accessed on November 22 (2015).

12. Sadikin., S. Nurmuin and M. F. Proceedings. Seminar Geomatika. Balai Penelitian Geomatika. Geospatial Information Centre. Cibinong. Indonesia. May 9 (2012).

13. Djaenuddin. Technical Report No. 7 ver. 1.0 Centre for Research and Development on Soil and Agro-climate. Bogor. (1994).

14. Purwowidodo. Book. Institut Pertanian Bogor Press. Bogor. (1999).

15. A. Dariah, Book. Ministry of Agriculture. Bogor. Indonesia (2004). 